\title{
Introduced non-native mangroves express better growth performance than co-occurring native mangroves
}

\begin{abstract}
Fatih Fazlioglu $\mathbb{1}^{1,2}$ \& Luzhen Chen $\mathbb{1}^{1 *}$
Mangroves are salt-tolerant woody species occurring in tropical/subtropical coastal habitats. Plantation of fast-growing non-native mangrove species has been used as a tool for mangrove restoration/ reforestation in several countries. However, the fast-growth ability can make recently introduced species invasive as they can possibly replace co-occurring native mangroves through expressing higher growth performance and phenotypic plasticity. Therefore, quantifying growth differences between native versus non-native mangrove species is important for forest ecology and management. In this meta-analysis, we compared the growth performance of non-native and native mangrove species pairs by analysing all available results in the literature (33 studies). We found that non-native mangrove species performed better than co-occurring native mangrove species in their introduced regions (Log response ratio $=0.51 \pm 0.05$ ) and they also expressed higher trait plasticity. Therefore, these species can be potentially invasive owing to their greater competitive advantage. However, the growth difference was diminished at higher latitudes where native mangrove species seem to perform as well as non-native mangrove species do. This is the first meta-analysis on the growth response of mangroves and it has consequential management implications. We suggest that planting of non-native mangrove species should be avoided and their spread should be monitored.
\end{abstract}

Mangroves are stress-tolerant species occupying coastal intertidal zones (along shores, rivers and estuaries) in the tropics and subtropics worldwide ${ }^{1}$. Despite their invaluable ecosystem goods and services, mangroves and the species depending on them are at an elevated extinction risk owing to coastal development, pollution, aquaculture, logging and biological invasion ${ }^{2,3}$. Globally, 20\% of the total area of mangroves has been lost between 1980 and $2005^{4}$. Similarly, global climate change (e.g., elevated temperature and sea-level rise) also threaten mangrove ecosystems by creating novel environments for mangroves where new abiotic factors (e.g., higher salinity) or biotic interactions may occur (e.g., competition with recently arrived species). Therefore, the ecological consequences of global climate change on mangrove ecosystems are not straightforward.

Biological invasion is also a major threat to mangrove ecosystems. Climate change can be a driving factor regarding invasive species performance. Abrupt range shifts in invasive species are expected under global climate change across biomes ${ }^{5,6}$. Different components of climate change (e.g., elevated atmospheric $\mathrm{CO}_{2}$, increased temperatures and changes in precipitation) trigger different responses in native and non-native species and therefore build more uncertainty regarding plant invasion status and appropriate management practices ${ }^{7}$. For example, increased $\mathrm{CO}_{2}$ can favour non-native species more than native species and facilitate biological invasions ${ }^{8,9}$. Therefore, the effect of biological invasion and global climate change interaction remains elusive but has critical importance, especially in mangrove forests.

Several terms have been used to describe invasive species in the literature (e.g., alien, nonnative, naturalized, nonindigenous, introduced and exotic). According to the definition by Richardson et al. (2000) an alien plant is an introduced species due to human activities in a certain area, whereas a naturalized plant is an alien plant that can constantly reproduce. Invasive plants are naturalized plants producing an excessive amount of offspring and potentially can spread across different areas ${ }^{10}$. Invasive species in mangrove forests are a serious problem and the

${ }^{1}$ Key Laboratory of the Ministry of Education for Coastal and Wetland Ecosystems, College of the Environment and Ecology, Xiamen University, Xiamen, Fujian, 361102, China. ${ }^{2}$ Faculty of Arts and Sciences, Department of Molecular Biology and Genetics, Ordu University, Ordu, 52200, Turkey. *email: Iuzhenchen@xmu.edu.cn 


\begin{tabular}{|c|c|c|c|c|}
\hline Species list & Origin & Introduced region & Introduction year & References \\
\hline \multicolumn{5}{|l|}{ Mangrove species } \\
\hline Avicennia marina & Indo-Pacific & California, USA & 1970 & 14 \\
\hline Bruguiera gymnorhiza & Indo-Pacific & $\begin{array}{l}\text { Hawaii, USA; } \\
\text { Florida, USA }\end{array}$ & $\begin{array}{l}1922 \\
1940\end{array}$ & 12,15 \\
\hline Excoecaria indica & Indo-Pacific & Bangladesh & - & 92 \\
\hline Laguncularia racemosa & Atlantic East Pacific & China & 1999 & 70 \\
\hline Lumnitzera racemosa & Indo-Pacific & Florida, USA; Tonga & 1960 & 12 \\
\hline Nypa fruticans & Indo-Pacific & $\begin{array}{l}\text { West Africa; } \\
\text { Caribbean }\end{array}$ & $\begin{array}{l}1906 \\
-\end{array}$ & 93,94 \\
\hline Rhizophora mangle & Florida, USA & Hawaii, USA & 1902 & 15 \\
\hline Rhizophora mucronata & Indo-Pacific & Hawaii, USA & 1922 & 15 \\
\hline Rhizophora racemosa & Indo-Pacific & Saudi Arabia & - & 95 \\
\hline Rhizophora stylosa & Indo-Pacific & French Polynesia & 1937 & 96 \\
\hline Sonneratia apetala & Bangladesh & China & 1985 & 13 \\
\hline Sonneratia caseolaris & Hainan, China & Shenzhen, China & - & 53 \\
\hline \multicolumn{5}{|l|}{ Mangrove associates } \\
\hline Conocarpus erectus & Florida, USA & Hawaii, USA & 1910 & 97 \\
\hline Pluchea carolinensis & Atlantic & Pacific islands & - & 17 \\
\hline Pluchea indica & Asia & Pacific islands & - & 17 \\
\hline Thespesia populnea & Asia & \begin{tabular}{|l} 
North America, \\
Caribbean
\end{tabular} & $\begin{array}{l}1928 \\
- \\
\end{array}$ & 97 \\
\hline \multicolumn{5}{|l|}{ Woody species } \\
\hline Annona glabra & Neotropics & Australia & 1912 & 98 \\
\hline Casuarina equisetifolia & Australia & $\begin{array}{l}\text { North America; } \\
\text { China; } \\
\text { South Africa }\end{array}$ & $\begin{array}{l}1924 \\
1950 \mathrm{~s} \\
- \\
\end{array}$ & 99-101 \\
\hline Melaleuca quinquenervia & Australia & $\begin{array}{l}\text { Florida, USA; } \\
\text { Bahamas }\end{array}$ & 1906 & 102,103 \\
\hline Schinus terebinthifolius & Neotropics & $\begin{array}{l}\text { Florida, USA; } \\
\text { Bahamas; } \\
\text { Australia }\end{array}$ & $\begin{array}{l}1891 \\
- \\
-\end{array}$ & 104 \\
\hline Syzygium fruticosum & Indo-Pacific & Bangladesh & - & 92 \\
\hline Tamarix indica & Indo-Pacific & Bangladesh & - & 92 \\
\hline
\end{tabular}

Table 1. Detailed information on introduced woody species invading different mangrove ecosystems in the world. Note: References were listed correspondingly depending on the introduced region.

main reason for introduced species is accidental introductions ${ }^{11}$. However, some mangrove species were intentionally introduced to restore mangrove habitats, and later these species became invasive such as Bruguiera and Rhizophora species in the USA ${ }^{12}$ and Sonneratia species in China ${ }^{13}$.

Many non-native woody species have also been introduced into mangrove forests in North America, Australia and Africa ${ }^{12-16}$ (see Table 1 for details). According to a global database of invasive species, there are at least 751 tree and shrub species which have been considered as invasive in the world ${ }^{17}$. Invasive species in mangrove forests were found to prevent the establishment and growth of mangroves, alter existing native vegetation composition, prevent regeneration, and affect ecosystem functioning ${ }^{11}$. For example, Hawaii had no native mangroves before the introduction of Rhizophora mangle in $1902^{15}$, and currently, there are at least six mangrove species in the archipelago. These introduced mangroves might have displaced some plant species in wetlands (e.g., Batis maritime, Paspalum vaginatum, Hibiscus tiliaceus and Thespesia populnea) $)^{18,19}$.

How do introduced species express better performance in growth and competition than native species and become invasive? According to the niche theory, non-native and native species those that have a similar niche cannot coexist but that have similar niche cannot coexist $\mathrm{t}^{20}$. However, trait-based coexistence theory contradicts the niche theory ${ }^{21}$. According to the coexistence theory, species abundance can determine its population growth rate and competitive interactions are the main factors shaping communities ${ }^{22}$. Species with high abundance and distribution (e.g., common native species) may have high intraspecific trait variation because of high habitat heterogeneity. However, high trait variation can be negatively correlated with species abundance in tropical tree seedlings ${ }^{23}$. In other words, occupying optimal trait values (low trait variation) can contribute to a higher spread of a particular species.

High establishment of non-native mangrove species in their introduced range can be linked with reduced propagule predation (e.g., Rhizophora mangle in Hawaii) ${ }^{24}$. Moreover, natural enemies may not co-migrate with introduced non-native species when these plants expand their ranges ${ }^{25}$. Therefore, an invasive species may invest more in its growth and competitive ability rather than defence due to lack of enemies in the introduced regions ${ }^{26}$ (i.e., the evolution of increased competitive ability - EICA hypothesis). Therefore, invasive woody species can express better performance than their congeneric or con-familial relatives ${ }^{27}$. 


\begin{tabular}{|c|c|c|c|c|}
\hline Invasive species & Traits measured & Key traits for invasiveness & Region & Reference \\
\hline 18 tree and 9 shrub species & RGR, NAR, LAR, LMR, SLA & RGR and SLA & Southwest USA & 56 \\
\hline 57 tree or shrub species & $\begin{array}{l}\text { SLA, height, flowering duration, rainfall } \\
\text { breadth, temperature breadth, biome } \\
\text { occupancy }\end{array}$ & Height and SLA & Australia & 105 \\
\hline Acacia longifolia & 20 traits & Shoot elongation & Europe & 28 \\
\hline Prunus serotina & 12 traits & $\begin{array}{l}\text { RGR, LAR, } A_{L} \text {, high plasticity in } \\
\text { light energy partitioning }\end{array}$ & Europe & 106 \\
\hline 13 Pinus species & 8 traits & RGR and SLA & Southwest USA & 107 \\
\hline 12 tree and 8 shrub species & SLA, CC, $A$, leaf nutrient concentration & SLA and $A$ & Hawaii, USA & 108 \\
\hline 4 tree species & 12 traits & RGR, LAR and $A$ & Hawaii, USA & 109 \\
\hline Rhus typhina & 12 traits & Height, LMR and $A$ & North China & 110 \\
\hline Robinia pseudoacacia & 9 traits & RGR and root biomass & Northeast China & 111 \\
\hline Acer platanoides & 15 traits & $A$ and WUE & Northeast USA & 112 \\
\hline Bischofia javanica & 18 traits & $\mathrm{AI}$ and the rate of leaf production & Japan & 113 \\
\hline 6 tree species & RGR, SLA, LAR, RSR, leaf nutrients & $\begin{array}{l}\text { SLA and high plasticity in LAR, } \\
\text { RSR and leaf nutrient contents }\end{array}$ & Seychelles & 114 \\
\hline
\end{tabular}

Table 2. Detailed information on studies comparing invasive and native woody species in terms of growth performance. Note: Relative growth rate (RGR), specific leaf area (SLA), net assimilation rate (NAR), leaf area ratio (LAR), leaf mass ratio (LMR), leaf mass to area ratio (LMA), total leaf area $\left(\mathrm{A}_{\mathrm{L}}\right)$, net $\mathrm{CO}_{2}$ assimilation $(A)$, leaf tissue construction cost (CC), water use efficiency (WUE), acclimation index (AI) and root:shoot ratio (RSR).

Non-native woody species can also be more competitive than native woody species by expressing greater phenotypic plasticity in biomass production which can be important in tree invasions ${ }^{28-30}$. Similarly, high phenotypic plasticity in biomass allocation in mangroves can be very beneficial for seedling establishment ${ }^{31}$. High plasticity in plant traits can allow mangroves to express higher tolerances to low temperature, aridity, salinity and nutrient scarcity ${ }^{32}$. Therefore, mangrove species with high phenotypic plasticity are more likely to adapt climate change by expressing optimal responses in changing environmental conditions.

Functional traits are biochemical, morphological, physiological, phenological traits which can affect the performance and fitness of an individual ${ }^{33,34}$. Variation in a functional trait of an individual can determine the performance and fitness of the individual and its population which, in turn, can affect the community and ecosystem-level processes ${ }^{35}$. Therefore, scaling up from trait level responses to the ecosystem level is possible ${ }^{36}$. For example, specific leaf area (SLA) in woody species is positively correlated with the niche breadth of a species ${ }^{37}$.

Functional traits can also explain the coexistence of plants more than environmental conditions (e.g., rainfall) and evolutionary relationships (e.g., phylogenetic distance $)^{38}$. Therefore, intraspecific trait plasticity can be a key factor to understand species fundamental niche and distribution ${ }^{35}$ as well as the invasive potential of a species ${ }^{39}$. For example, several studies indicated that higher values in some traits can be used as indicators of invasive tree species (Table 2). As a result, understanding variation in functional traits across non-native versus native mangrove species especially under changing environmental conditions caused by global climate change can be crucial for mangrove conservation.

Meta-analysis is one of the valuable methods to compare the growth performance of non-native and native mangroves ${ }^{40}$. Trait variation and plasticity comparisons between native versus non-native plants have been mostly studied in invasive herbaceous plants using meta-analyses ${ }^{9,41-43}$. However, woody invasive species were rarely examined (see Erskine-Ogden et al. 2016 for Mediterranean tree species) and, particularly no mangrove species were included in these meta-analyses. Although there are meta-analyses on mangrove productivity ${ }^{44}$, economic value $^{45}$ and carbon budget of mangroves ${ }^{46}$, there are no meta-analyses on the growth performance of mangrove species in the existing literature.

There are only a few number of experimental studies simultaneously compared the trait responses of both native and non-native mangrove species although biological invasion in mangroves had gained a lot of attention. Some studies focus on field surveys of non-native mangrove species, whereas others measured the response of either native or non-native mangrove species ${ }^{47-52}$. Quantifying growth differences between native and non-native species pairs under climate change is a knowledge gap in the literature. To address this knowledge gap, we compared the growth response of co-occurring native and non-native mangrove species across different regions by examining several key performance traits in a meta-analysis. We specifically asked: Do introduced non-native mangrove species express better growth performance than co-occurring native mangrove species in their introduced regions? Is there a latitudinal gradient in growth difference between non-native and native mangrove species? Moreover, we examined the current global status of introduced species in mangrove habitats and possible mangrove responses to climate change.

\section{Methods}

Literature search and study selection criteria. Quantitative and qualitative data were extracted from the literature using ISI Web of Science and China Knowledge Resource Integrated Database (CNKI) in 2019. Several keywords were used to find the most related papers for our meta-analysis including mangrove*, native*, naturalized, indig*, non-native*, nonnative*, alien*, nonindig*, non-indig*, exotic*, invasive* and combinations of these keywords. Following criteria were selected to be included in the analysis: (i) Comparative empirical 
studies must have at least two co-occurring mangrove species (e.g., a native and non-native species). (ii) Each study must measure at least one trait (either morphological or physiological trait). (iii) Each study must be at the species-level (community-level studies were excluded). "Native" or "non-native" groups were determined based on the species information presented in each publication. For example, Sonneratia caseolaris is native to Hainan, China but introduced to other regions in China ${ }^{53}$. Therefore, it was regarded as a native species in Hainan but non-native in Shenzhen, China.

In each study, a non-native mangrove species was paired with a co-occurring native mangrove species which was presented in the same study. In the case of several native and non-native species in a single study, several pairs were included in our analysis. These species pairs were regarded as independent data points ${ }^{43}$ as each study has a unique response ratio including biological and environmental variation ${ }^{54}$. The use of co-occurring species pairs, instead of different species from separate studies, provides more realistic comparisons between non-native and native mangrove species because the data will be from the same experimental conditions (e.g., the same treatment and trait response across species).

Extracted data and effect size. Quantitative data belonging to several traits, representing the growth and photosynthetic performance of mangrove species, were extracted (e.g., relative growth rate-RGR, tree height, specific leaf area, net photosynthetic rate) from tables, figures and Supplementary Files/appendices (if there are any) as these traits can be predictors of invasions ${ }^{55-57}$ (see also Table 2). The measuring tool in PDF-XChange Editor was used to detect values inside figures. Extracted data included species names, the origin of species (latitude), experiment type (field, survey, or greenhouse), treatment type (e.g., inundation, light, or salinity) and experimental conditions (e.g., habitat). To prevent pseudo-replication and include non-biased effect sizes, we extracted only one morphological and one physiological trait data from studies which met the criteria, and we preferably selected growth performance traits (e.g., RGR and net photosynthetic rate).

Log response ratio (LRR), that is widely used in meta-analysis studies, was preferred as an effect size to quantify the overall differences between growth differences between species pairs ${ }^{58}$ :

$$
\operatorname{LRR}=\operatorname{Ln}\left(\mathrm{X}_{\text {non }} / \mathrm{X}_{\text {nat }}\right)
$$

where $\mathrm{X}_{\text {non }}$ is the mean value in a growth trait of a non-native mangrove species and $\mathrm{X}_{\text {nat }}$ is the mean trait value in a growth trait of a native mangrove species.

The use of LRR allows growth performance comparison between species pairs to assess which species (non-native or native) performs well in particular environmental conditions (e.g., under high salinity or low light). If the overall value of LRR is greater than zero (lower 95\% confidence interval), growth performance in non-native woody species is greater than that in native species and vice versa. If LRR overlaps zero, there is no overall growth difference between non-native and native species.

Phenotypic plasticity calculation. In a subset of our dataset, we also used a plasticity index (PIv) $)^{59}$ to quantify phenotypic plasticity values in growth performance traits (the same traits used for the LRR) of native and non-native mangrove species pairs in China:

$$
\operatorname{PIv}=\left[\operatorname{Max}\left(\mathrm{X}_{\mathrm{c}}, \mathrm{X}_{\mathrm{t}}\right)-\operatorname{Min}\left(\mathrm{X}_{\mathrm{c}}, \mathrm{X}_{\mathrm{t}}\right)\right] / \operatorname{Max}\left(\mathrm{X}_{\mathrm{c}}, \mathrm{X}_{\mathrm{t}}\right)
$$

where $\mathrm{X}_{c}$ is the trait mean under control treatment; $\mathrm{X}_{\mathrm{t}}$ is the trait mean under a treatment (e.g., salinity or light). $\mathrm{PI}_{\mathrm{V}}$ is a common index that allows plasticity comparisons across species by illustrating the overall absolute change in trait means ${ }^{60,61}$. PIv values are always between 0 and 1 (representing no plasticity and maximum plasticity, respectively).

Statistical analyses. A two-way ANOVA was used to determine the effect of trait type, experiment type and their interaction on trait responses of mangrove species. In a Tukey's honestly significant difference (HSD) test, significant differences between trait, experiment type and their interaction were detected. In a paired sample $\mathrm{t}$-test, non-native mangrove species were paired with a native species in each study and $P$-values were calculated at 0.05 level. Regression analyses were used to determine the relationship between the mean log response ratio (LRR) values and latitudes. All statistical analyses were performed in JMP software v.13.2 (SAS Institute, NC, USA). Figures were prepared using SigmaPlot v.12 (Systat Software, CA, USA).

\section{Results}

Dataset and trait responses in mangroves. We extracted data from four non-native mangrove species belonging to two families (33 studies) which met our selection criteria to compare the growth performance of co-occurring native and non-native mangrove species. In our dataset, there were 220 data points including nine traits, seven treatment types and 74 different experimental conditions (Appendixes A and B). In each study, non-native mangrove species were matched with a co-occurring native mangrove species. In total, there were 21 different combinations of non-native versus native mangrove species comparisons (Kandelia candel in China is recognized as Kandelia obovata ${ }^{13,62}$ ) (Appendix C).

We found a significant, positive LRR value $(0.51 \pm 0.05)$ across all studies (Fig. 1 and Appendix A). That is, recently introduced non-native mangrove species expressed significantly higher values in growth-related morphological traits (e.g., RGR and leaf area) compared to co-occurring mangrove species. The growth performance difference between these species was much more pronounced in morphological traits than in physiological traits (Fig. 1). Similarly, in field and greenhouse experiments this difference was more apparent than in field survey studies. Moreover, in high latitudes (above $23^{\circ} \mathrm{N}$ ), the effect size was much lower than in other latitude categories. 


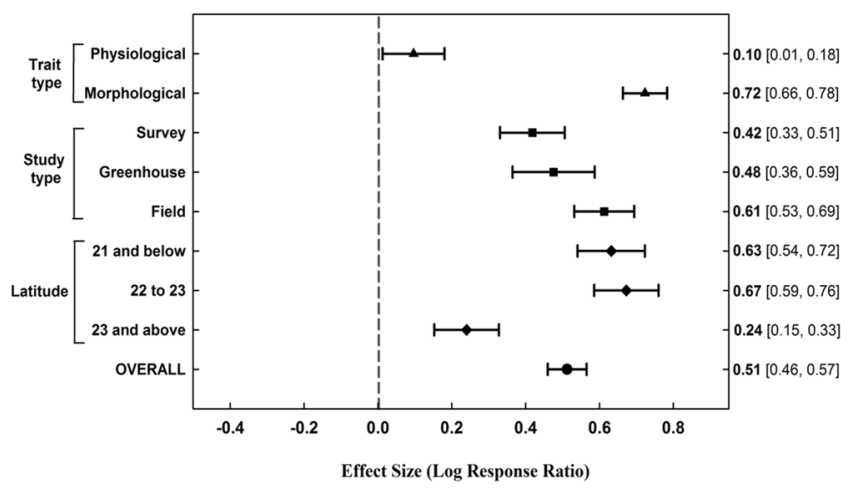

Figure 1. Forest plot indicating log Response Ratio (LRR) values and their 95\% bootstrapped confidence intervals (CIs) across different subgroups and overall data-set $(\mathrm{N}=220)$. Trait types indicate physiological traits $(\mathrm{n}=74)$ and morphological traits $(\mathrm{n}=146)$. Study types are field surveys $(\mathrm{n}=79)$, greenhouse experiment $(\mathrm{n}=49)$ and field experiment $(\mathrm{n}=92)$. Latitude categories are $21^{\circ} \mathrm{N}$ and below $(\mathrm{n}=69), 22$ to $23^{\circ} \mathrm{N}(\mathrm{n}=76)$ and $23^{\circ} \mathrm{N}$ and above $(\mathrm{n}=75)$.

\begin{tabular}{|l|l|l|l|}
\hline Non-native species & N & LRR Mean & LRR SE \\
\hline Laguncularia racemosa & 44 & 0.53 & 0.12 \\
\hline Lumnitzera racemosa & 24 & 0.57 & 0.19 \\
\hline Sonneratia apetala & 127 & 0.51 & 0.07 \\
\hline Sonneratia caseolaris & 25 & 0.45 & 0.07 \\
\hline Total & 220 & & \\
\hline
\end{tabular}

Table 3. Descriptive statistics for the mean log response ratio (LRR) values at the species level. Note: $\mathrm{N}$ is the sample size and SE stands for standard error.

Effect of trait and experiment types on mangrove responses. A two-way ANOVA test indicated significant differences between trait types and trait by experiment interaction (Appendix D). There were strong differences between studies comparing non-native and native mangrove species in terms of trait types and trait by experiment interaction (Appendix D). There were no greenhouse studies using mangrove species collected from low latitudes (less than $21^{\circ} \mathrm{N}$ ) and therefore a three-way ANOVA test was not possible to run for further analyses. Different Tukey's HSD tests indicated that morphological traits are significantly greater compared to physiological traits (Appendix E). In survey studies, LRR values were lower than in field and greenhouse experiments but the difference was not statistically significant. Moreover, greenhouse experiments measuring morphological traits found much higher values than greenhouse experiments measuring physiological traits.

At the species level, the highest mean LRR values were in Lumnitzera racemosa which was introduced to Florida, USA (Table 3), followed by Laguncularia racemosa, Sonneratia apetala and S. caseolaris, respectively. In the dataset, most data points belonged to Sonneratia apetala which has been well-studied in South China. We also examined mean LRR values through regression analysis at the species level across latitudes in South China by taking averages of LRR values for each species in each location and experiment type (Fig. 2). As survey studies provide more realistic data from the field, experiment types were presented separately in the figure (survey versus field and greenhouse experiments). Interestingly, as the latitudinal gradient increased, the growth difference between non-native and native mangrove species tended to decrease in survey studies (Fig. 2).

Trait plasticity comparison between native and non-native mangroves. We compared phenotypic plasticity of recently introduced $L$. racemosa and $S$. apetala with that of native species using a subset of our dataset (Appendix F) which contains only empirical studies that conducted a control and treatment on co-occurring mangrove species in China. Plasticity index values (PIv) in native species were calculated using arithmetic means of different native species presented in each study (e.g., Laguncularia racemosa versus Rhizophora stylosa and Kandelia obovata). We found that, on average, recently introduced non-native mangrove species expressed higher trait plasticity than native mangrove species in China (Table 4); however, the difference was not statistically significant according to paired sample t-test results.

\section{Discussion}

Performance of invasive and native mangrove species. High trait values in relative growth rate (RGR) and specific leaf area (SLA) are features of invasive tree species in the Mediterranean climate and these traits can be predictors of biological invasions ${ }^{56}$. In this study, we selected such key growth performance traits to assess the invasiveness potential of introduced mangrove species. Our results indicated that non-native mangrove species expressed higher values in growth performance traits (including RGR, height and photosynthetic traits) compared to co-occurring native mangrove species ( $L R R=0.51 \pm 0.05$; Fig. 1). Therefore, these introduced 


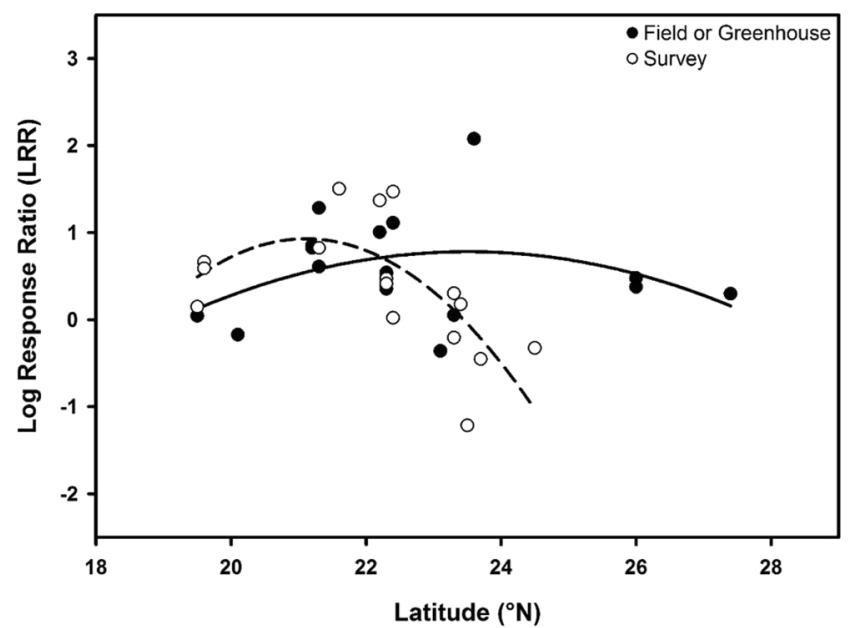

Figure 2. Regression analysis of mean log response ratio (LRR) values at the species level across latitudes in South China mangrove forests. The solid line indicates the regression line of field or greenhouse experiments $\left(R^{2}=0.12\right)$ and the dashed line indicates the regression line of survey studies $\left(R^{2}=0.48\right)$.

\begin{tabular}{|l|l|l|l|l|l|}
\hline Species pair group & N & $\begin{array}{l}\text { Mean PIv } \pm \text { SE in } \\
\text { non-native species }\end{array}$ & $\begin{array}{l}\text { Mean PIv } \pm \text { SE in } \\
\text { native species }\end{array}$ & t-Ratio & $\begin{array}{l}\text { Prob }>|\mathbf{t}| \\
(\boldsymbol{p} \text {-value })\end{array}$ \\
\hline Laguncularia racemosa versus native species & 16 & $0.41 \pm 0.04$ & $0.35 \pm 0.06$ & 1.15 & 0.27 \\
\hline Sonneratia apetala versus native species & 32 & $0.46 \pm 0.05$ & $0.40 \pm 0.05$ & 1.22 & 0.23 \\
\hline
\end{tabular}

Table 4. Paired sample t-test results of phenotypic plasticity index (PIv) for species pairs. Note: In each species pair group, a non-native species (e.g., L. racemosa or S. apetala) was matched with co-occurring native mangrove species. $\mathrm{N}$ is the sample size and SE stands for standard error.

mangrove species can be potentially invasive as a higher competitive advantage can favor biological invasions through better ability to benefit from fluctuating resource availabilities triggered by climate change (e.g., invasive tree species and associated traits listed in Table 2).

Invasion of new habitats (e.g., mangroves) depends on how fast populations can adapt to changing environmental conditions ${ }^{63}$. The competitive ability of non-native species can determine their invasion success ${ }^{39}$. As taller trees can intercept more light, tree height affects the competitive ability. If non-native species grow faster and perform better than co-occurring native species do by expressing higher phenotypic plasticity ${ }^{43}$, they can outcompete and even replace existing native mangrove species as global environmental changes can favor the spread of invasive plants ${ }^{9}$. In the case of non-native $S$. apetala invasion, forest structure can be significantly affected after the invasion and mangrove ecosystem functioning (e.g., carbon accumulation) may be changed ${ }^{64,65}$.

In this meta-analysis, most of the data points were from two recently introduced mangrove species (Sonneratia apetala and Laguncularia racemosa) in China. L. racemosa was introduced from La Paz, Mexico where is in an arid climatic zone and freshwater availability can increase its growth and productivity ${ }^{66}$. In Gulf of Mexico, low rainfall and high salinity prevent the movement of mangroves to higher latitudes ${ }^{67}$. However, at its site of introduction (Hainan, China), the mean annual rainfall is almost 9 times higher and salinity is 3 times lower than in La $\mathrm{Paz}, \mathrm{Mexico}{ }^{68-70}$. L. racemosa can outcompete native mangrove species (Rhizophora apiculata) in Hainan and it is reported to be spreading outside afforestation sites ${ }^{16}$. Moreover, L. racemosa can express high trait plasticity under environmental stresses including salinity and shade ${ }^{71}$. Therefore, L. racemosa can shift its range towards higher latitudes in China where salinity is lower and become potentially invasive owing to fast-growing characteristics, high germination rate, buoyant propagules, cold resistance, the ability to form dense monospecific stands ${ }^{70,72}$. These characteristics make L. racemosa a model species for afforestation but invoke questions regarding its invasive potential as it has frequently been used in mangrove afforestation since 2002 in China.

Sonneratia apetala is also an introduced fast-growing pioneer species (from Bangladesh) that can replace native species through competitive exclusion as it can grow better than native species ${ }^{73}$. In recently reforested areas in China, introduced $S$. apetala occupies approximately $50 \%$ of the replanted mangrove areas ${ }^{13}$. Moreover, the efficiency of $S$. apetala in using photosynthetic energy is higher than that in native mangrove species which can make the species invasive in South $\mathrm{China}^{74}$. Two mangrove species from the Indo-Pacific region planted in the US in 1940 have been invading tropical Atlantic forests ${ }^{12}$ and the same situation might be the case for L. racemosa in China whose origin is Atlantic East Pacific biogeographic zone.

When an invasive species is introduced to a new habitat, existing native plants may be more vulnerable to allelopathic chemicals originating from invasive species ${ }^{75}$ because such biochemicals produced by a mangrove species can prevent the germination, growth and survival of other mangrove species ${ }^{76}$ and therefore, determine mangrove forest succession (e.g., Kandelia species ${ }^{77}$ ). For example, allelopathic properties of introduced mangrove species such as L. racemosa and S. apetala may reduce the germination rate of seeds belonging to native mangrove 
species ${ }^{78}$ and therefore, affect the mangrove ecosystem functioning. As our meta-analysis indicated introduced mangrove species can outperform native mangrove species in their introduced regions, the invasive potential of non-native mangroves should be considered during mangrove afforestation and conservation management.

Mangrove responses to climate change. We found that there might be a negative correlation between growth performance differences in mangroves and the latitudinal gradient in China (Fig. 2). In higher latitudes, the growth difference between non-native and native mangrove species becomes ambiguous as native mangrove species seem to perform as well as non-native species. One of the reasons behind this trend might be the adaptation to low temperatures in winter ${ }^{79}$. At high latitudes, naturally occurring native mangroves are expected to perform better than recently introduced species because biochemical adaptations to colder temperatures would be necessary ${ }^{80}$, and these adaptations can be costly for non-native species in terms of competitive ability ${ }^{81}$. However, as species at high latitudes experience a reduced number of freezing events as a result of climate change, cold adaptation in native species may be maladaptive.

Mangrove species expressing high phenotypic plasticity are expected to be favoured under global climate change because plasticity can allow cold tolerance and being widespread ${ }^{82}$. We found that introduced mangrove species in China (S. apetala and L. racemosa) express higher plasticity than co-occurring native species do (Table 4). Therefore, they might be more successful in adapting to changing environmental conditions. Therefore, findings of this meta-analysis can also predict the distribution of mangrove species and possible range shifts in mangrove species under climate change.

If certain native mangrove species cannot express appropriate performance under changing environmental conditions, they might become extinct or move to different habitats to alleviate the detrimental effects of global climate change ${ }^{32,83}$ because mangroves can be highly sensitive to changes in climate ${ }^{84}$. Global climate change-induced cyclones, tsunamis, heat waves, and climatic extremes cause significant changes in mangrove mortality and recovery $^{85}$. Such events can reshape species composition and species abundance within mangrove ecosystems, and understanding mangrove responses to these changes is essential for mangrove ecosystem services.

Potential implications for forest management. This study is the first meta-analysis in the literature on the growth responses of mangrove species and it has far-reaching implications for mangrove management (e.g., conservation and restoration). Interestingly, only a very limited number of studies carried out experiments using multispecies including non-native and native mangrove species pairs although several woody species were introduced to different mangrove ecosystems across the world (Table 1). Most studies on mangroves in the literature report the presence of invasive species (e.g., references in Table 1). Therefore, findings of this meta-analysis may be somewhat limited by the lack of available data and low sample size (e.g., low $\mathrm{R}^{2}$ in Fig. 2). However, these findings can address the situation of mangroves in South China. Due to the use of non-native mangrove species (e.g., S. apetala) in afforestation in the past 30 years, the invasiveness of such species has been detected using either surveys or experiments ${ }^{13,53}$. The findings of our meta-analysis suggest the invasive potential of non-native mangrove species based on their superior growth performance compared to native species.

The relationship between growth performance at early life stages and invasiveness can be evaluated by the probability of dominance and dispersal which are two important aspects in predicting non-native species invasion in forests ${ }^{86}$. Most data in the present meta-analysis were from experimental comparisons on the growth and stress-tolerance of native and non-native species pairs, reflecting the early establishment of plants. According to our effect size (LRR), these non-native species performed better during the early establishment stages. Once they survive and dominate new habitats, they can be potentially invasive.

The early life stage is also an appropriate period to reduce the biological invasions by manipulating the degree of disturbance or productivity in forest management ${ }^{87}$. Shading, inundation or harvesting is the major measurements to control the invasiveness of a species ${ }^{88,89}$. Understanding how the introduced invasive and native species respond to changing environments will be a necessity for humankind to preserve robust ecosystem functioning. Therefore, in the future, more empirical studies are needed to better examine mangrove responses to biological invasions, particularly under global climate change.

The findings of this meta-analysis can be useful to predict the distribution of mangrove species and possible range shifts in mangrove species under climate change. On the global scale, climate change is a major challenge for woody plant invasion management which might accelerate the dispersal ability and growth performance of non-native species ${ }^{90}$. Our meta-analysis also examined stress tolerance to several environmental factors, such as inundation, salinity, light and temperature (Appendix A). As positive LRR values indicate, better performance of current non-native mangrove species can possibly lead to invasion. For instance, the poleward range limit of non-native $S$. apetala in China is around $28^{\circ} \mathrm{N}$ without reproduction, whereas it is $26.5^{\circ} \mathrm{N}$ with reproduction ${ }^{91}$. On the contrary, if certain native mangrove species cannot express better performance than non-native species (low LRR value) under changing environmental conditions, they might go extinct or move to different habitats to alleviate the detrimental effects of global climate change.

Our study also draws attention to the use of non-native mangrove species in afforestation practices and mangrove conservation management across the globe because introduced non-native species can outperform native mangrove species in their introduced ranges. We suggest that the invasion potential of non-native species should be considered and the use of introduced non-native mangrove species should be avoided in mangrove afforestation practices. Although ecological repercussions of non-native mangrove species invasion in mangrove forests are uncertain, such introduced non-native species should be monitored for their potential spread. Restoration and management of mangroves are crucial for socio-economic and scientific aspects which can be achieved through a better understanding of how mangrove species respond under global climate change and biological invasion. More empirical studies in the future can enhance our understanding of mechanisms behind invasions and possible methods to control the invasion in mangrove forests. 
Received: 10 October 2019; Accepted: 12 February 2020;

Published online: 02 March 2020

\section{References}

1. Twilley, R. R. \& Day, J. W. Mangrove wetlands. In Estuarine Ecology 165-202, https://doi.org/10.1002/9781118412787.ch7 (John Wiley \& Sons, Inc., 2013).

2. Duke, N. C. et al. A world without mangroves? Science $317,41 \mathrm{~b}-42 \mathrm{~b}$ (2007).

3. Giri, C. et al. Status and distribution of mangrove forests of the world using earth observation satellite data. Global Ecol. Biogeogr. 20, 154-159 (2011).

4. Spalding, M., Kainuma, M. \& Collins, L. World Atlas of Mangroves. (2010).

5. Bellard, C. et al. Will climate change promote future invasions? Global Change Biol. 19, 3740-3748 (2013).

6. Tomiolo, S. \& Ward, D. Species migrations and range shifts: A synthesis of causes and consequences. Perspect. Plant Ecol. 33, 62-77 (2018).

7. Bradley, B. A., Blumenthal, D. M., Wilcove, D. S. \& Ziska, L. H. Predicting plant invasions in an era of global change. Trends Ecol. Evol. 25, 310-318 (2010).

8. Sorte, C. J. B. et al. Poised to prosper? A cross-system comparison of climate change effects on native and non-native species performance. Ecol. Lett. 16, 261-270 (2013).

9. Liu, Y. et al. Do invasive alien plants benefit more from global environmental change than native plants? Global Change Biol. 23, 3363-3370 (2017).

10. Richardson, D. M. et al. Naturalization and invasion of alien plants: Concepts and definitions. Divers. Distrib. 6, 93-107 (2000).

11. Biswas, S. R. et al. Plant invasion in mangrove forests worldwide. Forest Ecol. Manag. 429, 480-492 (2018).

12. Fourqurean, J. W. et al. Are mangroves in the tropical Atlantic ripe for invasion? Exotic mangrove trees in the forests of South Florida. Biol. Invasions 12, 2509-2522 (2010).

13. Chen, L., Wang, W., Zhang, Y. \& Lin, G. Recent progresses in mangrove conservation, restoration and research in China. J. Plant Ecol. 2, 45-54 (2009).

14. Moran, R. Noteworthy collections: Avicennia marina var. resinifera. Madroño 27, 143 (1980).

15. Sauer, J. D. Plant Migration. The Dynamics of Geographic Patterning in Seed Plant Species. (University of California Press, 1988).

16. Chen, L. Invasive plants in coastal wetlands: Patterns and mechanisms. In Wetlands: Ecosystem Services, Restoration and Wise Use, Ecological Studies, https://doi.org/10.1007/978-3-030-14861-4_5(2019).

17. Rejmánek, M. \& Richardson, D. M. Trees and shrubs as invasive alien species - 2013 update of the global database. Divers. Distrib. 19, 1093-1094 (2013)

18. Allen, J. A. Mangroves as alien species: The case of Hawaii. Global Ecol. Biogeogr. 7, 61-71 (1998).

19. Walsh, G. E. An ecological study of a Hawaiian mangrove swamp. Estuaries (ed. byLauff, G. H.), pp. 420-431. American Association for the Advancement of Science Publication No. 83, Washington, D.C (1967).

20. MacDougall, A. S., Gilbert, B. \& Levine, J. M. Plant invasions and the niche. J. Ecol. 97, 609-615 (2009)

21. Hulme, P. E. \& Bernard-Verdier, M. Comparing traits of native and alien plants: Can we do better? Funct. Ecol. 32, 117-125 (2018).

22. HilleRisLambers, J., Adler, P. B., Harpole, W. S., Levine, J. M. \& Mayfield, M. M. Rethinking community assembly through the lens of coexistence theory. Ann. Rev. Ecol. Evol. Syst. 43, 227-248 (2012).

23. Umaña, M. N., Zhang, C., Cao, M., Lin, L. \& Swenson, N. G. Commonness, rarity, and intraspecific variation in traits and performance in tropical tree seedlings. Ecol. Lett. 18, 1329-1337 (2015).

24. Steele, O. C., Ewel, K. C. \& Goldstein, G. The importance of propagule predation in a forest of nonindigenous mangrove trees. Wetlands 19, 705-708 (1999).

25. Van der Putten, W. H., Macel, M. \& Visser, M. E. Predicting species distribution and abundance responses to climate change: Why it is essential to include biotic interactions across trophic levels. Philos. T. Roy. Soc. B. 365, 2025-2034 (2010).

26. Blossey, B. \& Notzold, R. Evolution of increased competitive ability in invasive nonindigenous plants: A hypothesis. J. Ecol. 83, 887-889 (1995)

27. Erskine-Ogden, J., Grotkopp, E. \& Rejmánek, M. Mediterranean, invasive, woody species grow larger than their less-invasive counterparts under potential global environmental change. Am. J. Bot. 103, 613-624 (2016).

28. Peperkorn, R., Werner, C. \& Beyschlag, W. Phenotypic plasticity of an invasive acacia versus two native Mediterranean species. Funct. Plant Biol. 32, 933-944 (2005).

29. Lamarque, L. J., Delzon, S. \& Lortie, C. J. Tree invasions: A comparative test of the dominant hypotheses and functional traits. Biol. Invasions 13, 1969-1989 (2011).

30. Kawaletz, H. et al. Exotic tree seedlings are much more competitive than natives but show underyielding when growing together. J. Plant Ecol. 6, 305-315 (2013).

31. Simpson, L. T., Osborne, T. Z. \& Feller, I. C. Establishment and biomass allocation of black and red mangroves: Response to propagule flotation duration and seedling light availability. J. Coast. Res. 335, 1126-1134 (2017).

32. Lovelock, C. E., Krauss, K. W., Osland, M. J., Reef, R. \& Ball, M. C. The physiology of mangrove trees with changing climate. In Tropical Tree Physiology 149-179, https://doi.org/10.1007/978-3-319-27422-5_7 (2016).

33. McGill, B. J., Enquist, B. J., Weiher, E. \& Westoby, M. Rebuilding community ecology from functional traits. Trends Ecol. Evol. 21, $178-85$ (2006)

34. Nock, C. A., Vogt, R. J. \& Beisner, B. E. Functional Traits. In Encyclopedia of Life Sciences 1-8, https://doi. org/10.1002/9780470015902.a0026282 (John Wiley \& Sons, Ltd, 2016).

35. Violle, C. et al. The return of the variance: Intraspecific variability in community ecology. Trends Ecol. Evol. 27, 244-252 (2012).

36. Funk, J. L. et al. Revisiting the Holy Grail: Using plant functional traits to understand ecological processes. Biol. Rev. 92, 1156-1173 (2017).

37. He, D., Chen, Y., Zhao, K., Cornelissen, J. H. C. \& Chu, C. Intra- and interspecific trait variations reveal functional relationships between specific leaf area and soil niche within a subtropical forest. Ann. Bot. 121, 1173-1182 (2018).

38. Soliveres, S. et al. Functional traits determine plant co-occurrence more than environment or evolutionary relatedness in global drylands. Pers. Plant Ecol. Evol. Syst. 16, 164-173 (2014).

39. Carboni, M., Calderon-Sanou, I., Pollock, L., Violle, C. \& Thuiller, W. Functional traits modulate the response of alien plants along abiotic and biotic gradients. Global Ecol. Biogeogr. 27, 1173-1185 (2018).

40. Gurevitch, J., Koricheva, J., Nakagawa, S. \& Stewart, G. Meta-analysis and the science of research synthesis. Nature 555, 175-182 (2018).

41. Funk, J. L. Differences in plasticity between invasive and native plants from a low resource environment. J. Ecol. 96, 1162-1173 (2008).

42. Van Kleunen, M., Weber, E. \& Fischer, M. A meta-analysis of trait differences between invasive and non-invasive plant species. Ecol. Lett. 13, 235-245 (2010).

43. Davidson, A. M., Jennions, M. \& Nicotra, A. B. Do invasive species show higher phenotypic plasticity than native species and, if so, is it adaptive? A meta-analysis. Ecol. Lett. 14, 419-31 (2011). 
44. López-Medellín, X. \& Ezcurra, E. The productivity of mangroves in northwestern Mexico: A meta-analysis of current data. J. Coast. Conserv. 16, 399-403 (2012).

45. Brander, M. L. et al. Ecosystem service values for mangroves in Southeast Asia: A meta-analysis and value transfer application. Ecosyst. Serv. 1, 62-69 (2012).

46. Davidson, I. C., Cott, G. M., Devaney, J. L. \& Simkanin, C. Differential effects of biological invasions on coastal blue carbon: A global review and meta-analysis. Global Change Biol. 24, 5218-5230 (2018).

47. Ball, M. C., Cochrane, M. J. \& Rawson, H. M. Growth and water use of the mangroves Rhizophora apiculata and R. stylosa in response to salinity and humidity under ambient and elevated concentrations of atmospheric $\mathrm{CO}^{2}$. Plant Cell. Environ. 20, $1158-1166$ (1997)

48. Naidoo, G. Effects of waterlogging and salinity on plant-water relations and on the accumulation of solutes in three mangrove species. Aquat. Bot. 22, 133-143 (1985).

49. Feller, I. C. Effects of nutrient enrichment on growth and herbivory of dwarf red mangrove (Rhizophora mangle). Ecol. Monogr. 65, 477-505 (1995).

50. Krauss, K. W., Young, P. J., Chambers, J. L., Doyle, T. W. \& Twilley, R. R. Sap flow characteristics of neotropical mangroves in flooded and drained soils. Tree Physiol. 27, 775-783 (2007).

51. Ye, Y., Tam, N. F. Y., Wong, Y. S. \& Lu, C. Y. Growth and physiological responses of two mangrove species (Bruguiera gymnorrhiza and Kandelia candel) to waterlogging. Environmental and Experimental Botany 49, 209-221 (2003).

52. McKee, K. L. Growth and physiological responses of neotropical mangrove seedlings to root zone hypoxia. Tree Physiol. 16, 883-889 (1996).

53. Zeng, X. et al. Seedling emergence and dispersal pattern of the introduced Sonneratia caseolaris in Shenzhen Bay, China. Biodivers. Sci. 16, 236-244 (2008).

54. Nakagawa, S. \& Santos, E. S. A. Methodological issues and advances in biological meta-analysis. Evol. Ecol. 26, 1253-1274 (2012).

55. Mihulka, S., Pysek, P., Martinkova, J. \& Jarosik, V. Invasiveness of Oenothera congeners alien to Europe: Jack of all trades, master of invasion? Pers. Plant Ecol. Evol. Syst. 8, 83-96 (2006).

56. Grotkopp, E. \& Rejmánek, M. High seedling relative growth rate and specific leaf area are traits of invasive species: Phylogenetically independent contrasts of woody angiosperms. Am. J. Bot. 94, 526-532 (2007).

57. Leishman, M. R., Haslehurst, T., Ares, A. \& Baruch, Z. Leaf trait relationships of native and invasive plants: Community- and global-scale comparisons. New Phyt. 176, 635-643 (2007).

58. Hedges, L. V., Gurevitch, J. \& Curtis, P. S. The meta-analysis of response ratios in experimental ecology. Ecology 80, 1150-1156 (1999).

59. Valladares, F., Wright, S., Lasso, E. \& Kitajima, K. Plastic phenotypic response to light of 16 congeneric shrubs from a Panamanian rainforest. Ecology 81, 1925-1936 (2000).

60. Valladares, F., Sanchez-Gomez, D. \& Zavala, M. A. Quantitative estimation of phenotypic plasticity: Bridging the gap between the evolutionary concept and its ecological applications. J. Ecol. 94, 1103-1116 (2006).

61. Gratani, L., Catoni, R., Pirone, G., Frattaroli, A. R. \& Varone, L. Physiological and morphological leaf trait variations in two Apennine plant species in response to different altitudes. Photosynthetica 50, 15-23 (2012).

62. Sheue, C.-R., Liu, H.-Y. \& Yong, J. W. H. Kandelia obovata (Rhizophoraceae), a new mangrove species from Eastern Asia. Taxon 52, 287-294 (2003).

63. Davis, M. B., Shaw, R. G. \& Etterson, J. R. Evolutionary responses to changing climate. Ecology 86, 1704-1714 (2005).

64. Ren, H. et al. Sonneratia apetala Buch.Ham in the mangrove ecosystems of China: An invasive species or restoration species? Ecol. Eng. 35, 1243-1248 (2009).

65. Lu, W. et al. Changes in carbon pool and stand structure of a native subtropical mangrove forest after inter-planting with exotic species Sonneratia apetala. PLoS ONE 9, e91238 (2014).

66. Osland, M. J., Enwright, N. \& Stagg, C. L. Freshwater availability and coastal wetland foundation species: Ecological transitions along a rainfall gradient. Ecology 95, 2789-2802 (2014).

67. Osland, M. J. et al. Mangrove forests in a rapidly changing world: Global change impacts and conservation opportunities along the Gulf of Mexico coast. Estuarine, Coastal and Shelf Science 214, 120-140 (2018)

68. Félix-Pico, E. F., Holguín-Quiñones, O. E., Hernández-Herrera, A. \& Flores-Verdugo, F. Producción primaria de los mangles del Estero El Conchalito en Bahía de La Paz (Baja California Sur, México). Ciencias Marinas 32, 53-63 (2006).

69. Chen, L. et al. Comparison of ecophysiological characteristics between introduced and indigenous mangrove species in China. Estuar. Coast. Shelf S. 79, 644-652 (2008).

70. Zhong, C. R., Shi-Chuan, L. I., Yang, Y. C., Zhang, Y. \& Lin, Z. W. Analysis of the introduction effect of a mangrove species Laguncularia racemosa. J. Fujian Forest Sci. Tech. 38, 96-99 (2011).

71. Gu, X. et al. Predicting the invasive potential of a non-native mangrove reforested plant (Laguncularia racemosa) in China. Ecol. Eng. 139, 105591 (2019).

72. Wang, X., Zhou, L. \& Lu, C. Do environmental factors affect the male frequency of exotic mangrove species Laguncularia racemosa (Combretaceae) along the southeast coast of China? Aquat. Ecol. 52, 235-244 (2018).

73. Ren, H. et al. Restoration of mangrove plantations and colonisation by native species in Leizhou bay, South China. Ecol. Res. 23, 401-407 (2008)

74. Li, F. L. et al. Are photosynthetic characteristics and energetic cost important invasive traits for alien Sonneratia species in south China. PLoS ONE 11, 1-19 (2016)

75. Morgan, E. C. \& Overholt, W. A. Potential allelopathic effects of Brazilian pepper (Schinus terebinthifolius Raddi, Anacardiaceae) aqueous extract on germination and growth of selected Florida native plants. J. Torrey Bot. Soc. 132, 11-15 (2005).

76. Kathiresan, K. \& Bingham, B. L. Biology of mangroves and mangrove Ecosystems. In Advances in Marine Biology 81-251, https:// doi.org/10.1016/S0065-2881(01)40003-4 (Elsevier, 2001).

77. Chen, L., Peng, S., Chen, B., Li, J. \& Pang, J. Effects of Aqueous extracts of 5 mangrove spp. on cabbage germination and hypocotyl growth of Kandelia candel. Allelopathy J. 23, 469-476 (2009).

78. Zhang, Y. et al. Allelopathic effects of leachates from two alien mangrove species, Sonneratia apetala and Laguncularia racemosa on seed germination, seedling growth and antioxidative activity of native mangrove species Sonneratia caseolaris. Allelopathy J. 44, 119-130 (2018).

79. Stuart, S. A., Choat, B., Martin, K. C., Holbrook, N. M. \& Ball, M. C. The role of freezing in setting the latitudinal limits of mangrove forests. New Phyt. 173, 576-583 (2007).

80. Woodward, F. I. Climate and plant distribution. Cambridge University Press. (1987).

81. Madrid, E. N., Armitage, A. R. \& Lopez-Portillo, J. Avicennia germinans (black mangrove) vessel architecture is linked to chilling and salinity tolerance in the Gulf of Mexico. Front. Plant Sci. 5, 1-9 (2014).

82. Goldstein, G., Santiago, L. S. Tropical Tree Physiology. (Springer International Publishing, 2016).

83. Osland, M. J. et al. Mangrove expansion and contraction at a poleward range limit: climate extremes and land-ocean temperature gradients. Ecology 98, 125-137 (2017).

84. Cavanaugh, K. C. et al. Sensitivity of mangrove range limits to climate variability. Global Ecol. Biogeogr. 27, 925-935 (2018).

85. Sippo, J. Z., Lovelock, C. E., Santos, I. R., Sanders, C. J. \& Maher, D. T. Mangrove mortality in a changing climate: An overview. Estuar. Coast. Shelf S. 215, 241-249 (2018). 
86. Huebner, C. D., Regula, A. E. \& McGill, D. W. Germination, survival, and early growth of three invasive plants in response to five forest management regimes common to US northeastern deciduous forests. Forest Ecol. Manag. 425, 100-118 (2018).

87. Huston, M. A. Management strategies for plant invasions: Manipulating productivity, disturbance, and competition. Divers. Distrib. 10, 167-178 (2004).

88. Dangremond, E. M., Feller, I. C. \& Sousa, W. P. Environmental tolerances of rare and common mangroves along light and salinity gradients. Oecologia 179, 1187-1198 (2015).

89. Peng, Y. et al. Early growth adaptability of four mangrove species under the canopy of an introduced mangrove plantation: Implications for restoration. Forest Ecol. Manag. 373, 179-188 (2016).

90. Pyšek, P. et al. Contrasting patterns of naturalized plant richness in the Americas: Numbers are higher in the North but expected to rise sharply in the South. Global Ecol. Biogeogr. 28, 779-783 (2019).

91. Chen, L. Invasive Plants in Coastal Wetlands: Patterns and Mechanisms. In Wetlands: Ecosystem Services, Restoration and Wise Use, Ecological Studies, S An, JTA., https://doi.org/10.1007/978-3-030-14861-4_5 (2019).

92. Biswas, S. R., Choudhury, J. K., Nishat, A. \& Rahman, M. M. Do invasive plants threaten the Sundarbans mangrove forest of Bangladesh? Forest Ecol. Manag. 245, 1-9 (2007).

93. Saenger, P., Bellan, M. F. The mangrove vegetation of the Atlantic coast of Africa. (Université de Toulouse Press, 1995).

94. Duke, N. C. Nypa in the mangroves of Central America: Introduced or relict? Principes 35, 127-132 (1991).

95. Sheppard, C., Price, A. \& Roberts, C. Marine ecology of the Arabian region: Patterns and processes in extreme tropical environments. (Academic Press, 1992).

96. Langer, M. R. \& Lipps, J. H. Assembly and persistence of foraminifera in introduced mangroves on Moorea, French Polynesia. Micropaleontology 52, 343-355 (2007).

97. Swearingen, J., Bargeron, C. Invasive Plant Atlas of the United States. (University of Georgia Center for Invasive Species and Ecosystem Health, 2016).

98. Meyer, J. Y. Invasive plants in the Pacific Islands. In The Invasive Species in the Pacific: A Technical Review and Draft Regional Strategy (ed. Sherley, G.) (SPREP, 2000).

99. Elfers, S. C. Element stewardship abstract for Casuarina equisetifolia. (The Nature Conservancy, 1988).

100. Liu, X., Lu, Y., Xue, Y. \& Zhang, X. Testing the importance of native plants in facilitation the restoration of coastal plant communities dominated by exotics. Forest Ecol. Manag. 322, 19-26 (2014).

101. Henderson, L. \& Wilson, J. R. U. Changes in the composition and distribution of alien plants in South Africa: An update from the Southern African Plant Invaders Atlas. Bothalia 47, a2142 (2017).

102. Fuller, D. O. Remote detection of invasive Melaleuca trees (Melaleuca quinquenervia) in South Florida with multispectral IKONOS imagery. Int. J. Remote Sens. 26, 1057-1063 (2005).

103. Pratt, P. D., Rayamajhi, M. B., Van, T. K., Center, T. D. \& Tipping, P. W. Herbivory alters resource allocation and compensation in the invasive tree Melaleuca quinquenervia. Ecol. Entomol. 30, 316-326 (2005).

104. Cuda, J. P., Ferriter, A. P., Manrique, V. M. J. Brazilian Peppertree Task Force Chair. Interagency Brazilian Peppertree (Schinus terebinthifolius) Management Plan for Florida. (Recommendations from the Brazilian Peppertree Task Force Florida Exotic Pest Plant Council, 2006).

105. Gallagher, R. V., Randall, R. P. \& Leishman, M. R. Trait differences between naturalized and invasive plant species independent of residence time and phylogeny. Conserv. Biol. 29, 360-369 (2015).

106. Robakowski, P., Bielinis, E. \& Sendall, K. Light energy partitioning, photosynthetic efficiency and biomass allocation in invasive Prunus serotina and native Quercus petraea in relation to light environment, competition and allelopathy. J. Plant Res. 131, 505-523 (2018).

107. Grotkopp, E., Rejmanek, M. \& Rost, T. L. Toward a causal explanation of plant invasiveness: Seedling growth and life-history strategies of 29 pine (Pinus) species. Am. Nat. 159, 396-419 (2002).

108. Baruch, Z. \& Goldstein, G. Leaf construction cost, nutrient concentration, and net $\mathrm{CO} 2$ assimilation of native and invasive species in Hawaii. Oecologia 121, 183-192 (1999).

109. Pattison, R. R., Goldstein, G. \& Ares, A. Growth, biomass allocation and photosynthesis of invasive and native Hawaiian rainforest species. Oecologia 117, 449-459 (1998)

110. Yuan, Y. et al. Competitive interaction between the exotic plant Rhus typhina L. and the native tree Quercus acutissima Carr. in Northern China under different soil N:P ratios. Plant Soil 372, 389-400 (2013).

111. Luo, Y. et al. Increased nitrogen deposition alleviated the competitive effects of the introduced invasive plant Robinia pseudoacacia on the native tree Quercus acutissima. Plant Soil 385, 63-75 (2014).

112. Kloeppel, B. D. \& Abrams, M. D. Ecophysiological attributes of the native Acer saccharum and the exotic Acer platanoides in urban oak forests in Pennsylvania, USA. Tree Physiol. 15, 739-746 (1995).

113. Yamashita, N., Koike, N. \& Ishida, A. Leaf ontogenetic dependence of light acclimation in invasive and native subtropical trees of different successional status. Plant Cell. Environ. 25, 1341-1356 (2002).

114. Schumacher, E., Kueffer, C., Edwards, P. J. \& Dietz, H. Influence of light and nutrient conditions on seedling growth of native and invasive trees in the Seychelles. Biol. Invasions 11, 1941-1954 (2009).

\section{Acknowledgements}

This study was jointly supported by the National Key Research and Development Program of China (2017YFC0506103), the National Natural Science Foundation of China (\#31770579), the Fundamental Research Funds for the Central Universities of China (20720180118), the Key Laboratory of the Coastal and Wetland Ecosystems (WELRI201601) and the State Key Laboratory of Marine Environmental Science (MELRI1603).

\section{Author contributions}

L.C. initiated the study. F.F. designed the study with comments from L.C. F.F. extracted and analysed data. F.F. drafted the manuscript. Both authors participated in the writing of the manuscript and the review process. Both authors read and approved the final manuscript.

\section{Competing interests}

The authors declare no competing interests.

\section{Additional information}

Supplementary information is available for this paper at https://doi.org/10.1038/s41598-020-60454-z.

Correspondence and requests for materials should be addressed to L.C.

Reprints and permissions information is available at www.nature.com/reprints. 
Publisher's note Springer Nature remains neutral with regard to jurisdictional claims in published maps and institutional affiliations.

(c) (i) Open Access This article is licensed under a Creative Commons Attribution 4.0 International License, which permits use, sharing, adaptation, distribution and reproduction in any medium or format, as long as you give appropriate credit to the original author(s) and the source, provide a link to the Creative Commons license, and indicate if changes were made. The images or other third party material in this article are included in the article's Creative Commons license, unless indicated otherwise in a credit line to the material. If material is not included in the article's Creative Commons license and your intended use is not permitted by statutory regulation or exceeds the permitted use, you will need to obtain permission directly from the copyright holder. To view a copy of this license, visit http://creativecommons.org/licenses/by/4.0/.

(c) The Author(s) 2020 